\title{
High frequency of the HRAS oncogene codon 12 mutation in Macedonian patients with urinary bladder cancer
}

\author{
Sasho Panov ${ }^{1}$, Danica Roganovic-Zafirova ${ }^{1}$, George Stavric ${ }^{2}$, Genghis Yashar $^{2}$ and Zivko Popov ${ }^{3}$ \\ 1 "St. Cyril and Methodius" University, Faculty of Natural Sciences and Mathematics, \\ Department of Biology, Laboratory of Molecular Biology, Skopje, Republic of Macedonia. \\ 2 "St. Cyril and Methodius" University, Institute of Radiotherapy and Oncology, Medical Faculty, \\ Department of Histopathology and Clinical Cytology, Vodnjanska bb, Skopje, Republic of Macedonia. \\ 3 "St. Cyril and Methodius" University, Medical Faculty, Clinical Center, Urologic Clinic, \\ Vodnjanska bb, Skopje, Republic of Macedonia.
}

\begin{abstract}
Point mutations at codon 12 of the HRAS (v-Ha-ras Harvey rat sarcoma viral oncogene homolog) oncogene are one of the best defined and widely studied molecular genetic events in transitional cell carcinoma (TCC) of the urinary bladder. The aim of this study was to use the polymerase chain reaction-restriction fragment length polymorphism (PCR-RFLP) analysis of paraffin-embedded tissue-derived DNA to determine the frequency of the HRAS oncogene $\mathrm{G} \rightarrow \mathrm{T}$ codon 12 mutation in TCC patients being treated at the University Urology Clinic in Skopje, Republic of Macedonia. DNA isolated from paraffin-embedded tissue (PET) surgically removed TCC specimens of $62(81.58 \%)$ out of 76 patients were successfully amplified, the remaining $14(18.42 \%)$ showing compromised DNA integrity. The codon 12 mutation of the HRAS oncogene was found in 24 (38.71\%) out of 62 successfully tested TCC urinary bladder samples. No significant relationship between the mutation frequency and the histopathological grade of tumor differentiation was detected $\left(\chi^{2}=0.044 ; p=0.978\right)$. The relatively high frequency of mutations found in our study was comparable with some of the previously reported data obtained by this and/or other PCR-based methods. This highly sensitive and specific PCR-RFLP analysis was demonstrated to be a suitable method for the detection of mutations at codon 12 of the HRAS oncogene in PET samples of urinary bladder TCC.
\end{abstract}

Key words: HRAS, oncogene, bladder cancer, PCR-RFLP.

Received: August 19, 2002; Accepted: October 6, 2003.

\section{Introduction}

Transitional cell carcinoma (TCC) of the urinary bladder is the most common urothelial neoplasm in the urinary tract and one of the most frequent malignancies found in the human population (Steiner et al., 1997, Ozen, 1998). The molecular genetics of TCC has been extensively studied and reviewed (Levesque et al., 1993 Hovey et al., 1998, Knowles, 1999, Jung and Messing, 2000, Knowles, 2001). One of the best-defined molecular events in TCC and in some other neoplasms is point mutation at the 'hot-spot' positions of the HRAS (v-Ha-ras Harvey rat sarcoma viral oncogene homolog) oncogene (Saito, 1992, Ooi et al., 1994, Reznikoff et al., 1996, Ross et al., 1996, Saito et al., 1997, Pfister et al., 2000). The G $\rightarrow$ T substitution at the

Send correspondence to Sasho Panov. "St. Cyril and Methodius" University, Faculty of Natural Sciences and Mathematics, Department of Biology, Laboratory of Molecular Biology, P.O. Box 162, 1000 Skopje, Republic of Macedonia. E-mail: sasho@mt.net.mk. codon 12 of the $H R A S$ oncogene leads to a glycine to valine change and consequently to an activated protein $\mathrm{p} 21$, in a permanently guanosine 5'-triphosphate (GTP)-bound state, possessing dominant oncogenic potential (Jung and Messing, 2000). About twenty years ago, Taparowsky et al. (1982) elegantly demonstrated the transforming potential of the mutant HRAS oncogene by transfection of the NIH $3 \mathrm{~T} 3$ cell line with a human bladder cancer-derived clone of the HRAS oncogene. Further research on the genetics of urothelial malignant transformation, including sequencing analyses (Caponet et al., 1983, Willumsen et al., 1986, Knowles et al., 1993, Levesque et al., 1993, Burchil et al., 1994), has found that codon 12 mutations are the most frequently affected single 'hot-spot' position in the HRAS oncogene (Czerniak et al., 1990, Fitzgerald et al., 1995, Cristaudo et al., 1997, Jung and Messing, 2000).

The amplification power of methods based on the polymerase chain reaction (PCR) has greatly improved the understanding of molecular abnormalities associated with 
urothelial malignant transformation (Ross et al., 1996, Steiner et al., 1997, Bonnal et al., 2000, Christensen et al., 2000, Friedrich et al., 2000, Phillips et al., 2000). Retrospective investigations of archived paraffin-embedded tissue (PET) from patients with a known clinical outcome can be useful in evaluation of the prognostic significance of defined molecular events, such as HRAS mutations in TCC patients (Czerniak et al., 1990). However, histopathological processing of surgical samples leads to various degrees of DNA degradation and consequently compromises the quality and quantity of DNA isolates (Greer et al., 1995). This type of DNA source requires the careful selection of highly sensitive detection method to avoid the possibility of misdetecting mutations. Restriction fragment length polymorphism (RFLP) analysis of PCR-amplified DNA has proven to be a very sensitive method for the detection of known mutations, with up to $100 \%$ specificity being reported under optimized conditions (Nollau and Wagener, 1997).

In the present study, we used PCR-RFLP to retrospectively evaluated the frequency of point mutation at codon 12 of the HRAS oncogene in PET surgical samples taken from patients with urinary bladder TCC.

\section{Materials and Methods}

\section{Methodology}

The investigation was performed on archived PET material from 76 patients with urinary bladder TCC (61 male, 15 female, mean age $64.27 \pm 30.5$ years), $85.5 \%$ of the patients being ethnic Macedonians, $13.2 \%$ Albanians and $1.3 \%$ Serbs. Surgical samples had been obtained by transuretral resection, biopsy and/or partial or total cystectomy (performed at the University Urology Clinic in Skopje, Republic of Macedonia) and had been formalin-fixed and paraffin-embedded using the routine procedures in place at the histopathology laboratory of the same hospital. The archived PET samples used in our study were all less than 2 years old and were selected from the histopathology laboratory PET archive and assessed by clinical pathologists according the degree of histological differentiation of the tissues (Bane et al., 1996), lower levels of differentiation indicating more advanced TCC. The pathologists divided the samples into three TCC groups: TCC grade 1, containing the most differentiated samples; TCC grade 2, containing samples with an intermediate level of differentiation; and TCC grade 3, containing the least differentiated samples. Genomic DNA isolated from a T24 human bladder tumor cell line was used as a positive control for the presence of point mutation at codon 12 of the HRAS oncogene (Taparowsky et al., 1982; Capon et al., 1983). Human leukocyte DNA from a healthy subject was used as a negative control (Steiner et al., 1997). This study was approved by the Ethical Committee of the Medical Council of the Republic of Macedonia.

\section{Isolation of DNA}

Depending on tissue area, 10 to $35 \mathrm{~mm}$ sections were taken from each paraffin block, de-paraffinized with xylene, washed in absolute ethanol and air-dried; all under strict conditions designed to reduce cross-contamination of the samples (Greer et al., 1995). Protein digestion was performed by incubating the dried specimens overnight at $55{ }^{\circ} \mathrm{C}$ with lysis buffer $(50 \mathrm{mM}$ Tris $\mathrm{HCl}, \mathrm{pH} 8.5 ; 1 \mathrm{mM}$ EDTA; $0.5 \%$ Tween $20 ; 0.01 \%$ Proteinase K) using $100 \mathrm{~mL}$ of buffer per 10-20 mg of dried tissue. DNA was isolated using lithium chloride/chloroform extraction followed by ethanol precipitation (Gemmell and Akiyama, 1996, Wolff and Gemmil, 1997). The concentration of DNA and of contaminating protein was determined by UV-spectrophotometry and DNA integrity evaluated by agarose gel-electrophoresis.

\section{PCR amplification}

The amplification of a 123-bp sequence which included codon 12 of the HRAS oncogene (Levesque et al., 1993, Burchil et al., 1994) was performed using the HPLC-purified oligonucleotide primer pair H12A/H12B (sense: $\quad 5$ '-atgacggaatataagctggt-3'; antisense: 5'-cgccaggctcacctctata-3') (MycroSynth, Balgach, Switzerland). Each amplification mix was assembled in a final volume of $25 \mu \mathrm{L}$ of PCR buffer $(50 \mathrm{mM} \mathrm{KCl} ; 10 \mathrm{mM}$ Tris $\mathrm{HCl}, \mathrm{pH} 9.0$ at $25^{\circ} \mathrm{C} ; 1.5 \mathrm{mM} \mathrm{MgCl} 2 ; 0.1 \%$ Triton ${ }^{\circledR}$ $\mathrm{X}-100$ ) containing: $200 \mu \mathrm{M}$ dNTP mix; $1 \mu \mathrm{M}$ each of sense and antisense primer; $0.5 \mathrm{U}$ Taq polymerase and $200 \mathrm{ng}$ of template DNA. The reaction mixtures were amplified in a GeneAmp PCR System 2400 thermocycler (Perkin Elmer, Norwalk, CT) using the following cycling profile: initial denaturation $\left(5 \mathrm{~min}\right.$ at $\left.95{ }^{\circ} \mathrm{C}\right)$; followed by 30 cycles of three steps each: denaturation $\left(15 \mathrm{~s}\right.$ at $\left.95^{\circ} \mathrm{C}\right)$, annealing $(30$ s at $\left.56^{\circ} \mathrm{C}\right)$ and extension $\left(30 \mathrm{sec}\right.$ at $\left.72^{\circ} \mathrm{C}\right)$. After completing the last cycle, terminal extension was applied (7 min at $\left.72{ }^{\circ} \mathrm{C}\right)$. All PCR reagents were obtained from Promega, (Madison, WI).

\section{RFLP analysis}

An aliquot of each PCR-amplified sample was subjected to restriction digestion at $37^{\circ} \mathrm{C}$ for $4 \mathrm{~h}$ in a final volume of $20 \mu \mathrm{L}$ of digestion buffer ( $25 \mathrm{mM}$ Tris-acetate, $\mathrm{pH}$ 7.8; $100 \mathrm{mM}$ potassium acetate; $1 \mathrm{mM}$ dithiothreitol) containing: $10 \mu \mathrm{L}$ unpurified amplified DNA; $100 \mu \mathrm{g} / \mathrm{mL}$ acetylated bovine serum albumin (BSA); $10 \mathrm{U}$ MspI (Promega, Madison, WI). Both undigested and MspI-digested aliquots of each amplified sample, along with positive (T24 cell line DNA) and negative (human leukocyte DNA) control samples and a DNA size marker (20-1000 bp molecular ruler (Bio-Rad, Hercules, CA) were subjected to electrophoreses on non-denaturing $10 \%$ polyacrylamide gels and visualized under UV-light after ethidium bromide staining. 


\section{Results and Discussion}

The DNA isolated from PET specimens of 62 $(81.58 \%)$ out of 76 patients were successfully amplified and, as expected, yielded 123 bp PCR products. The remaining $14(18.42 \%)$ of isolates showed extensive DNA degradation after control agarose gel electrophoresis and were not included in the investigation.

Digestion of non-mutated (wild-type) $123 \mathrm{bp}$ amplicons with restriction endonuclease MspI results in two bands (one for a $91 \mathrm{bp}$ fragment and one for a $32 \mathrm{bp}$ fragment) while amplicons harboring the codon $12 \mathrm{G} \rightarrow \mathrm{T}$ mutation are digestion-resistant and produce just one band representing the intact $123 \mathrm{bp}$ product. Because tumor cells are diploid they are, theoretically, heterozygous for the codon $12 \mathrm{G} \rightarrow$ T mutation and PCR-RFLP analysis of a pure population of malignant cells should result in bands for both the undigested $123 \mathrm{bp}$ PCR product and two digestion fragments (one of 91 and another of $32 \mathrm{bp}$ ) with the intensity of the UV-induced ethidium bromide fluorescence of the undigested electrophoretic band being equal to the sum of the fluorescence intensities of the two digestion products.

The results obtained by our PCR-RFLP analysis of the HRAS oncogene codon $12 \mathrm{G} \rightarrow \mathrm{T}$ mutation are shown in Figure 1. In our experiments, the intensity of the fluorescence of the bands corresponding to undigested and digested PCR products differed considerably between samples. In most of the samples harboring the codon 12 $\mathrm{G} \rightarrow \mathrm{T}$ mutation the fluorescence of the $91 \mathrm{bp}$ and $32 \mathrm{bp}$ bands (corresponding to the digested PCR products representing the unmutated wild-type gene) was more intense than that of the undigested $123 \mathrm{bp}$ band (Figure 1, line 6).

In contrast to non-neoplastic normal cells, neoplastic tissue (especially established cancer cell lines) contain multiple and often uncharacterized chromosomal abnormalities (amplifications, aneuploidy, polyploidy, translocations, inversions, deletions, etc.) that change the proportion of normal and mutant alleles. Since we performed no micro-dissection on our PET samples the proportion of neoplastic to normal tissue in each sample remained as it was (i.e. undetermined) in the original tumor, leading to different amounts of mutant $H R A S$ alleles in samples from different patients and, consequently, to the observed differences in the intensity of fluorescence between the non-mutant and mutant digested (wilde-type) PCR products. Since our restriction digestion was performed to completion under optimized conditions, the appearance of even only a light band of undigested PCR products would be indicative of the presence of mutant DNA in the original sample.

The PCR-RFLP analysis of the DNA isolated from the T24 cell line (homozygous for the codon $12 \mathrm{G} \rightarrow \mathrm{T}$ mutation) used as a positive control was completely diges-

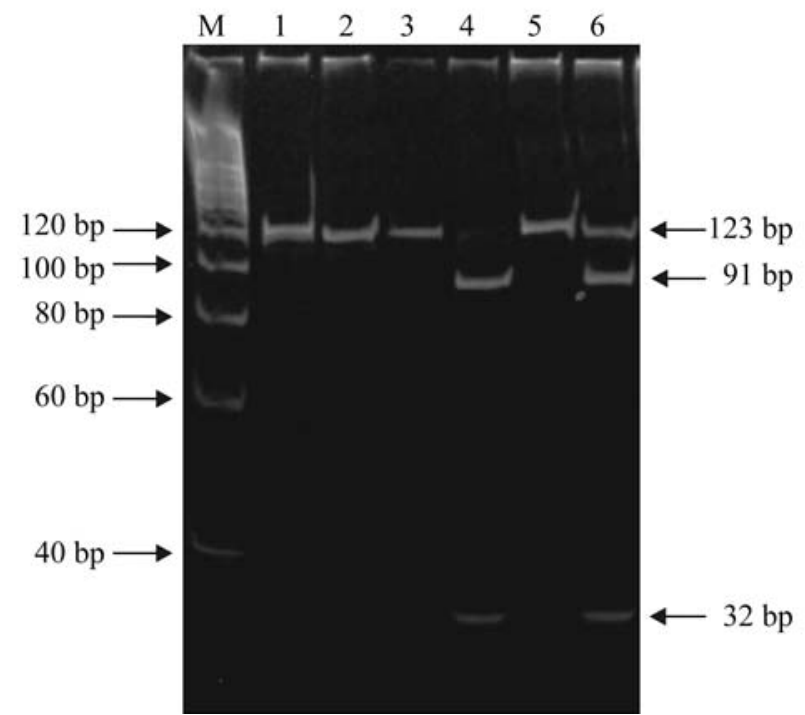

Figure 1 - Detection of the $\mathrm{G} \rightarrow \mathrm{T}$ mutation at codon 12 of $H R A S$ oncogene by PCR-RFLP analysis. On a $10 \%$ polyacrylamide gel: line M, molecular weight marker; lanes 1 and 2, positive control (T24 cell line DNA), undigested and MstI - digested, respectively; lanes 3 and 4, sample without the mutation, undigested and digested, respectively; lanes 5 and 6: sample with the mutation, undigested and digested, respectively.

tion-resistant and only one $123 \mathrm{bp}$ electrophoretic band appeared on the gel (Figure 1, lines 1 and 2).

PCR amplification and RFLP analysis revealed the 12 $\mathrm{G} \rightarrow \mathrm{T}$ point mutation at codon 12 of the HRAS oncogene in $24(38.71 \%)$ out of 62 tested samples. Seven out of 19 patients $(36.84 \%)$ with TCC grade 1 , ten out of $26(38.46 \%)$ with TCC grade 2 , and seven out of $17(41.18 \%)$ with TCC grade 3 were found to have the $12 \mathrm{G} \rightarrow \mathrm{T}$ mutation (Table 1).

The point mutations of the HRAS oncogene is relatively common in various human neoplasms and usually affects 'hot-spot' positions at codons 12, 13, 59 and 63 (Manam and Nichols, 1991, Burchil et al., 1994, Jung and Messing, 2000), but in this paper we will restrict our discussion to the $\mathrm{G} \rightarrow \mathrm{T}$ point mutation at codon 12 of the HRAS oncogene because the majority of previous reports indicate that this is the most frequent $H R A S$ mutation in urinary bladder TCC (Czerniak et al., 1990, Burchil et al., 1991). However, the reported incidence of codon 12 HRAS codon

Table 1 - Distribution of patients according to $\mathrm{G} \rightarrow$ T mutation at codon 12 of the $H R A S$ oncogene and histopathological grade of transitional cell carcinoma (TCC) differentiation.

\begin{tabular}{lccc}
\hline & \multicolumn{2}{c}{$\begin{array}{c}\text { Histopathological grade Showing number of patients } \\
\text { in each grade (bold type) and percentage (\%) }\end{array}$} \\
\cline { 2 - 4 } $\begin{array}{l}\text { HRAS G } \rightarrow \mathrm{T} \\
\text { mutation }\end{array}$ & TCC 1 & TCC2 & TCC 3 \\
\hline Positive & $7(36.84)$ & $10(38.46)$ & $7(41.18)$ \\
Negative & $12(63.16)$ & $16(61.54)$ & $10(58.82)$ \\
Total $(\mathrm{n}=62)$ & $19(30.64)$ & $26(41.94)$ & $17(27.42)$ \\
\hline
\end{tabular}


12 mutations in urinary bladder TCC display broad range between different studies (Burchil et al., 1991, Saito, 1992, Levesque et al., 1993, Burchil et al., 1994, Hong et al., 1996). For example, while Knowles and Williamson (1993) found a very low frequency of the HRAS mutation (2.63\%) using Single-Strand Conformation Polymorphism (SSCP), RFLP and direct sequencing, Fitzgerland et al. (1995), also using SSCP analysis, reported a mutation frequency of $44 \%$ for exon 1 (which includes codon 12). In our study we found that the frequency of tumors with codon 12 mutations of the $H R A S$ oncogene was relatively high at $38.71 \%$, this being comparable to the $36.36 \%$ frequency reported by Czerniack et al. (1990) who used allele-specific oligonucleotide hybridization to detect this mutation. In addition, we have also detected a high prevalence of the HRAS codon 12 mutation in another study of patients with bladder cancer (Panov et al., 2002).

The discrepancy in the reported incidence of mutations at codon 12 of the HRAS oncogene may be due to many different factors, including ethnic specificity, environmental exposure, exposure in the workplace, variability in the proportion of malignant to stromal and normal urothelial cells in the tissue specimen or to the degree of heterogeneity within the tumor cell population, as well as the type of methodology used to detect this type of mutation. In our research, different samples showed variation in the intensity of fluorescence of the electrophoretic bands corresponding to digested and undigested PCR products, probably due to both the different proportions of malignant versus stromal tissue and the presence of normal urothelial cells in the PET samples.

Regarding the sensitivity of the currently available methodology, it has been demonstrated that direct sequencing can detect a mutant allele when at least 12.5\% (Burchil et al., 1994) to $20 \%$ (Knowles and Williamson, 1993) of cells in a tissue sample contain the mutation. Fitzgerald et al. (1995) reported that SSCP analysis required approximately $10 \%$ of mutated cells in order to be effective, while Knowles and Williamson (1993) found that mismatched primer extension techniques needed 6 to $10 \%$ of mutation-bearing cells in order to be effective. The extraordinary sensitivity of PCR-RFLP analysis has been demonstrated by Hong et al. (1996), who reported that even $0.1 \%$ of cells harboring mutated DNA mixed in normal DNA was detectable. Although, because of the amplification power of the PCR, extreme care must be taken to avoid cross-contamination of samples by previous PCR products. Under optimal conditions, including the use of a positive control, almost no false negative or positive results can be expected from PCR-RFLP analyses (Nollau and Wagener, 1997). In our study, we performed all DNA isolation and PCR assembling separately from the post-PCR manipulations using stringent rules for preventing cross-contamination of samples and also repeated analysis of randomly selected samples, these random replications always pro- ducing the same results. To ensure that there are no restriction endonuclease inhibitors present in the amplified DNA before digestion with $M s p I$ enzyme, aliquots of the product of amplification can be digested with a different enzyme that recognizes a restriction site other than that of the expected mutation. The above data supports the usefulness of PCR-RFLP analysis as a sensitive, specific and convenient method for the detection of mutations at codon 12 of the $H R A S$ oncogene in archived PET samples.

The use of PET in PCR-based molecular genetic studies has resulted in many exciting new insights into cancer research, molecular epidemiology and other related areas. Due to the intrinsic properties of this type of tissue source, the success of any PCR-based method involving PET material depends on several factors, including the type of fixative used in tissue processing, duration of fixation, the age of the paraffin block and the length of DNA fragment to be amplified. Greer et al. (1995) reported considerable variation in the quality of the DNA of PET specimens derived from different institutions. In the study, 62 isolates $(81.58 \%)$ out of 76 PET specimens were successfully amplified. Our results gave a lower percentage of successful DNA isolation in comparison to that found by Greer et al. (1995) using PET samples of comparable age and an amplification product of a comparable length. The difference between our results and those of Greer et al. (1995) may have been due to delayed or prolonged tissue fixation or other tissue-processing factors used in the original preparation of our PET samples, such factors sometimes resulting in a significant decrease in the length of amplifiable DNA sequences. Even so, the proportion of amplifiable DNA isolates obtained in our investigation supports the view that PET samples are acceptable for use in methods involving the PCR-based detection of the HRAS oncogene codon 12 mutation in bladder TCC. This methodology apears to be an appropriate for detecting mutations and amplifying DNA sequences up to $200 \mathrm{bp}$ in length (Greer et al., 1995).

In the present study, no significant association was observed between mutation frequency and the histological grade of differentiation $\left(\chi^{2}=0.044 ; p=0.978\right)$. The almost even distribution of mutations in all three TCC grades support the assumption that, when present, point mutations at codon 12 in the HRAS oncogene are an early molecular genetic event in the pathogenesis of bladder tumors (Burchil et al., 1994, Hong et al., 1996). The role of the ras gene in uroepithelial oncogenesis has also been supported by immunochemical studies, such as that conducted by Fontana et al. (1996) who found a correlation between overexpression of the c-ras oncogene product (p21) and recurrence of the superficial bladder cancer samples. However, in our and other reported studies, the majority of urinary bladder neoplasms have no detectable mutations affecting the HRAS gene, implying that other or alternative molecular pathways may be involved in the events leading to the stimulation of cell proliferation in bladder cancer 
(Levesque et al., 1993, Cairns and Sidransky, 1998, Shields et al., 2000). Such molecular events may activate the same RAS $>$ RAF $>$ MEK $>$ MAPK circuitry or deregulate the parallel pathways leading to abnormal mitogenic growth signals and/or changes in normal gene expression (Hanahan and Weinberg 2000, Hahn and Weinberg, 2002).

\section{Acknowledgments}

We are deeply grateful to Mr. L. Sumanovski from the Department of Research, Cantonal Hospital at the University of Basel, Switzerland, for helpful suggestions and for supplying the DNA from the T24 cell line.

\section{References}

Bane BL, Rao JY and Hemstreet GP (1996) Pathology and staging of bladder cancer. Seminars in Oncology 23:546-570.

Bonnal C, Ravery V, Toublanc M, Bertrand G, Boccon-Gibod L, Henin D and Grandchamp B (2000) Absence of microsatellite instability in transitional cell carcinoma of the bladder. Urology 55:287-291.

Burchil SA, Lunec J, Mellon K and Neal DE (1991) Analysis of Ha-ras mutations in primary bladder tumors. Brit J Cancer 63 (Suppl. 3):62.

Burchil SA, Neal DE and Lunec J (1994) Frequency of HRAS mutations in human bladder cancer detected by direct sequencing. Br J Urology 73:516-521.

Capon DJ, Chen EY, Levinson AD, Seeburg PH and Goeddel DV (1983) Complete nucleotde sequences of the T24 human bladder carcinoma oncogene and its normal homologue. Nature 302:33-37.

Cairns P and Sidransky D (1998) Bladder cancer. In: Vogelstein B and Kinzler KW (eds) The genetic basis of human cancer. McGraw-Hill, New York, pp 639-645.

Christensen M, Wolf H and Orntoft TF (2000) Microsatellite alterations in urinary sediments from patients with cystitis and bladder cancer. Int J Cancer 85:614-617.

Cristaudo A, Vivaldi A, Guglielmi G, Sensales G and Ottenga F (1997) A simple method to reveal possible ras mutations in DNA of urinary sediment cells. J Environ Pathol Toxicol Oncol 16:201-204.

Czerniak B, Deitch D, Simmons H, Etkind P, Herz F and Koss LG (1990) Ha-ras gene codon 12 mutation and DNA ploidy in urinary bladder carcinoma. Br J Cancer 62:762-763.

Fitzgerald JM, Ramshurren N, Reiger K, Levesque P, Silverman M, Libertino JA and Summerhayes IC (1995) Identification of HRAS mutations in urine sediments complements cytology in the detection of bladder tumors. J Natl Cancer Inst 87:129-133.

Fontana D, Bellina M and Scoffone C (1996) Evaluation of c-ras oncogene product (p21) in superficial bladder cancer. Eur Urol 29:470-476.

Friedrich MG, Erbersdobler A, Schwaibold H, Conrad S, Huland E and Huland H (2000) Detection of loss of heterozygosity in the p53 tumor-suppressor gene with PCR in the urine of patients with bladder cancer. J Urol 163:1039-1042.

Gemmell NJ and Akiyama S (1996) An efficient method for the extraction of DNA from vertebrate tissues. Trends in Genetics 12:338-339.
Greer CE, Cosette MW and Manos MM (1995) PCR Amplification from paraffin-embedded tissues: Sample preparation and the effects of fixation. In: Dieffenbach $\mathrm{CW}$ and Dveksler GS (eds) PCR Primer. A Laboratory Manual. Cold Spring Harbor Laboratory Press, Cold Spring Harbor, New York, pp 99-112.

Hahn WC and Weinberg R (2002) Modeling the molecular circuitry of cancer. Nature Reviews Cancer 2:331-341

Hanahan D and Weinberg R (2000) The hallmarks of cancer. Cell 100:57-70.

Hong SJ, Lee T, Park YS, Lee KO, Chung BH and Lee SH (1996) A PCR-RFLP method for the detection of activated HRAS oncogene with point mutation at codon 12 and 61 . Yonsei Medical Journal 37:371-379.

Hovey RM, Chu L, Balazs M, DeVries S, Moore D, Sauter G, Carroll PR and Waldman FM (1998) Genetic alterations in primary bladder cancers and their metastases. Cancer Res 58:3555-3560.

Jung I and Messing E (2000) Molecular mechanisms and pathways in bladder cancer development and progression. Cancer Control 7:325-334.

Knowles MA and Williamson M (1993) Mutation of HRAS is infrequent in bladder cancer: Confirmation by single-strand conformation polymorphism analysis, designed restriction fragment length polymorphism, and direct sequencing. Cancer Res 53:133-139.

Knowles MA (1999) The genetics of transitional cell carcinoma: progress and potential clinical application. BJU Int 84:412427.

Knowles MA (2001) What we could do now: molecular pathology of bladder cancer. J Clin Pathol: Mol Pathol 54:215221.

Levesque P, Ramchurren N, Saini K, Joyce A, Libertino J and Summerhayes IC (1993) Screening of human bladder tumors and urine sediments for the presence of HRAS mutations. Int J Cancer 55:785-790.

Manam SS and Nichols WW (1991) Multiple polymerase chain reaction amplification and direct sequencing of homologous sequences: Point mutation analysis of the ras gene. Anal Biochem 199:106-111.

Nollau P and Wagener C (1997) Methods for detection of point mutations: performance and quality assessment. Clinical Chemistry 43:1114-1128.

Ooi A, Herz F, Ii S, Cordon-Cardo C, Fradet Y, Mayall BH and The NIH Network for Bladder Cancer (1994) Ha-ras codon 12 mutation in papillary tumors of the urinary bladder: a retrospective study. Int J Oncol 4:85-90.

Ozen H (1998) Bladder cancer. Curr Opin Oncol 10:273-278.

Panov S, Roganovic-Zafirova D, Jovcheva E, Gligorov D, Markoska M and Popov Z (2002) Urinary samples in molecular genetic detection of bladder cancer. Balcan Journal of Clinical Laboratory IX:79.

Pfister C, Larue H, Moore L, Lacombe L, Veilleux C, Tetu B, Meyer F and Fradet Y (2000) Tumorigenic pathways in low-stage bladder cancer based on p53, MDM2 and p21 phenotypes. Int J Cancer 89:100-104.

Phillips HA, Howard GC and Miller WR (2000) p53 mutations as a marker of malignancy in bladder washing samples from patients with bladder cancer. Br J Cancer 82:136-141. 
Reznikoff CA, Belair CD, Yeager TR, Savelieva E, Blelloch RH, Puthenveettil JA and Scott C (1996). A molecular genetic model of human bladder cancer pathogenesis. Seminars in Oncology 23:571-584.

Ross RK, Jones PA and Mimi CY (1996) Bladder cancer epidemiology and pathogenesis. Seminars in Oncology 23:536-545.

Saito S (1992) Detection of HRAS gene point mutations in transitional cell carcinoma of human urinary bladder using polymerase chain reaction. Keio J Med 41:80-86.

Saito S, Hata M, Fukuyama R, Sakai K, Kudoh J, Tazaki H and Shimizu N (1997) Screening of H-ras gene point mutations in 50 cases of bladder carcinoma. Int J Urol 4:178-85.

Shields JM, Pruit K, McFall A, Shaub A and Der CJ (2000) Understanding Ras: "it ain't 'til it's over". Trends in Cell Biology 10:147-154.
Steiner G, Schoenberg MP, Linn JF, Mao L and Sidransky D (1997) Detection of bladder cancer recurrence by microsatelite analysis of urine. Nature Medicine 3:621-624.

Taparowsky E, Suard Y, Fasano O, Shimizu K and Goldfarb M (1982) Activation of the T24 bladder carcinoma transforming gene is linked to a single amino acid change. Nature 300:762-765.

Willumsen BM, Papageorge AG, Kung HF, Bekesi E, Robins T, Johnsen M, Vass WC and Lowy DR (1986) Mutational analysis of a ras catalytic domain. Mol Cell Biol 6:2646-2654.

Wolff R and Gemmil R (1997) Purifying and analyzing genomic DNA. In: Birren B, Green ED, Klapholz S, Myers RM and Roskams J (eds) Genome analysis. A laboratory manual. Cold Spring Harbor Laboratory Press, Cold Spring Harbor, New York, pp 1-81.

Editor: Angela M. Vianna-Morgante 